UJBM, Vol. 6, No. 2, July - December 2007, pp 75-82

ISSN 0975-3311 | https://doi.org/10.12725/ujbm.11.7

\title{
MANAGING WORK LIFE BALANCE - ROLE OF HR DEPARTMENT IN IT SECTOR
}

\author{
R. Venkataraman*
}

ABSTRACT:
The world has changed beyond recognition with a rapid pace of change
as never seen before. This sea change has affected all facets of human
existence and behaviour and posed new challenges for the people at
the helm of affairs. The corporate scene is one of confusion and
challenge, with competition and customer-orientation becoming the
focus. There are new strategies and also new concepts to help the
corporate. On account of increase in competition, the organisation
has to face lot of challenges. Organisations are facing challenges to
retain good employees, to pay good salary and also insist them to
perform effectively which in furn increases the workload on an individual
and leaves less time for the family or for other interests and hobbies. A
balanced life is one where an individual gets sufficient opportunity to
distribute his/her energy for his development and growth, which include
emolional satisfaction, professional satisfaction and spiritual growth.
This calls for the balance between various aspects of life such as career
family and other interests. If any one of the aspects is ignored, it will
lead to a frustration not only for the individual but also for the people
concerned with his/her life.

* Faculty of Management studies, New Horizon College, Bangalore. 


\subsection{Introduction:}

Work life balance is about developing a modern and more productive economy in Birmingham. It incorporates policies for family friendly employment. Everyone has a life outside of work. It is not just people with families who have responsibilities and commitments. Getting the work-life balance right helps us all to operate more effectively. Work life balance is a person's control over the conditions in their workplace. It is accomplished when an individual feels dually satisfied about their personal life and their paid occupation. It mutually benefits the individual, business and society when a person's personal life is balanced with his or her own job. The work-life balance strategy offers a variety of means to reduce stress levels and increase job satisfaction in the employee while enhancing business benefits for the employer. In our increasingly hectic world, the work-life strategy seeks to find a balance between work and play. A sentence that brings the idea of work life balance to the point is "Work to live. Don't live to work."

It is still up to discussion though, if a harsh separation between "work" and "ife" is a perfect solution. One may argue that work is very much a part of life. Finding the right job, that is fun to do, might be the more important part in removing possible causes of stress.

Work life balance is basically between a person's commitment for both family, personal interests and hobbies and work time. Work life balance is being aware of different demands on fime and energy having the ability to make choices in the allocation of time and energy knowing what values to apply to choices making choices

\subsection{Objectives of Study:}

The study is undertaken with the objectives given below:

To study the professionals commitment for both family, personal interests and hobbies and work time.

To study the Human resource practices prevailing in maintaining the work life balance.

To find the factors that helps in managing the work life balance

To offer suggestions to the professionals which will help them to balance the work life. 


\subsection{Scope of the study:}

The sfudy is aimed at examining the factors such as marriage, major personal injury/illness, pregnancy etc which has the impact on work life and also the strategies adopted by the professionals for balancing the work life. The scope of the study is confined to study of respondents of Bangalore city.

\subsection{Limitations of the study:}

Every study has its own limitations.

The size of the sample is restricted. The limitations of restricted sample size is also applicable to the present study.

The availability of data are limited by time factor.

\subsection{Review of literature:}

A number of studies have been undertaken by various individuals and institutions on managing the work life. Such studies have enabled the researcher to have deep insight into the existing state. In addition, the previous studies have also enabled the researcher to identify the changing outlook and attitude of professionals in the present day.

G. Balakrishnan in his study titled "Balancing work life" has studied the data relating to stress, wellness programme and has suggested various measures to reduce the stress like meditation, rejuvenation etc.

Dr. L.C. Gupta (1994) conducted a survey for balancing the worklife and has suggested various facilities to be implemented in the organization such as gym, swimming pool and flexitime. According to Vloeberghs, 2002 research it appears that employees now-a-days seem to value the quality of life more than the amount of salary they get.

N. Santhi and Shanthi Nachiappan (2006) conducted a research with reference to IT sector in Chennai and suggested measures like working from home, fringe leave and flexi time to balance the work life.

Mr. Shanmugham, (2006) studied a group of 90 employees in Chennai and suggested measures like family atmosphere, meditation facilities, gym and flexi time to balance the work life. 


\subsection{Methodology:}

The fundamental success of any research is purely depends on construction of sound research design. A research design is purely and simply the framework or plan for a study that guides the collection and analyis of the data. The researcher has adopted descriptive research with simple random sampling for the study. The researcher considered 50 respondents for the study.

\subsection{Data collection:}

Two types of data were collected for the study. They are primary data and secondary data.

a) Primary Data

Primary data are those which are collected originally by the researcher for the purpose of his study. The researcher collected primary data from the respondents through a questionnaire.

b) Secondary Data:

The study depended also on the secondary data. The secondary data were collected from standard textbooks of related topic, journals and reports.

\subsection{Analysis of data:}

Analysis of data involves a number of closely related operations with the purpose of summarizing the collected data and organizing these in such a manner that they will yield answer to the research questions or suggest hypothesis or questions if no such questions or hypothesis has initiated in the study. Francis Rummel has pointed out that "the analysis and interpretation of data involve the objective material in the possession of the researcher and his subjective reaction and desires to derive from the data the inherent meaning in the relation to the problem". 


\section{Table 1}

No of working hours

\begin{tabular}{|l|c|c|c|}
\hline S.no & No of Respondents & Percentage & $\begin{array}{c}\text { No of working } \\
\text { hours }\end{array}$ \\
\hline 01 & 27 & 54 & 11 \\
\hline 02 & 09 & 18 & 10 \\
\hline 03 & 10 & 20 & 09 \\
\hline 04 & 04 & 08 & 8 to 9 \\
\hline Total & 50 & 100 & \\
\hline
\end{tabular}

Table 1 has disclosed that $54 \%$ of the respondents work for 11 hours, $18 \%$ of the respondents work for 10 hours, $20 \%$ of the respondents work for 9 hours \& $8 \%$ of the respondents work between 8 to 9 hours.

\section{Table 2}

\section{Factors responsible for balancing work life}

\begin{tabular}{|l|c|c|c|}
\hline S.no & $\begin{array}{c}\text { Factors responsible } \\
\text { to balance work life }\end{array}$ & No of respondents & Percentage \\
\hline 01 & Organization & 10 & 20 \\
\hline 02 & Employees & 15 & 30 \\
\hline 03 & Both are responsible & 25 & 50 \\
\hline Total & & 50 & 100 \\
\hline
\end{tabular}

Table 2 reveals that $20 \%$ of the respondents felt that organization is responsible for balancing the work life, $30 \%$ of the respondents felt that employees is responsible for balancing their work life, $50 \%$ of the respondents felt that both organization and employees are responsible for balancing Worklife. 


\section{Table 3}

Ranking \& Priority

\begin{tabular}{|l|l|l|}
\hline S.no & \multicolumn{1}{|c|}{ Factors } & Ranking \\
\hline 01 & Family & 4.2 \\
\hline 02 & Employer & 4.1 \\
\hline 03 & Working conditions & 3.9 \\
\hline 04 & Financial \& Non financial incentives & 2.7 \\
\hline
\end{tabular}

Table 3 discloses that the executives have ranked family as top most factor followed by employer, followed by working conditions and the least preference is given to financial and non financial incentives.

\section{Chi Square Test:}

Variables $=$ Work at home and balancing the work life.

HO: There is no significance association between working at home and balancing the work life.

$\mathrm{H1}$ : There is a significance association between working at home and balancing the work life.

Level of significance $=5 \%$

Degree of freedom $=1$

$\chi 20.05,2=3.81$

$\chi 2 \mathrm{cal}=2.95$

Inference: Since the calculated value is less than the table value, hypothesis $\mathrm{HO}$ is accepted. Therefore there is no significance association between working at home and balancing the work life. 


\subsection{Suggestions \& Conclusion:}

\section{Suggestions}

a) Foremost is providing flexible working hours for the employees by the employers. Options should be given to the employees such as having a compressed work week or job sharing. A compressed work week involves working full-time hours in a four days in order to provide a longer weekend and more time for leisure activities.

b) The company should review the work-life balance of their employees on a regular balance. Employers can provide individual development plans for employees or mentoring by colleagues in order to monitor progress and satisfaction in the workforce. Guidelines to handle problems should also be established so business and personal needs can be met.

c) Adequate leave options should also be provided to the employees. In addition to holiday leave, parental leave and time off for dependants and maternity leave, leave should be provided for new fathers or additional schooling. Employees can also be assisted by their employer if they provide information on local care providers, local day care centers or loans to help pay for eldercare. These assistances would help ease the stress of home life.

d) Encouraging wellness to improve health: If employees are encouraged to protect their health, this will enable them to deal more effectively with unavoidable stresses at work. Organisations can help by offering health screening, subsidized private healthcare, on-site exercise facilities or subsidized access to gyms, etc

e) Unproductive meeting should be avoided so that the employees can concentrate on their work whereby they can save time.

\section{Conclusion}

Satisfied employees contribute to greater business benefits for the employer. Foremost, businesses would experience an increase in productivity. Happy employees perform better than disgruntled and stressed ones. Businesses would also see improved recruitment and retention. Additionally, there would be lower rates of absenteeism and improved customer service. Overall, there would exist a more motivated, satisfied and equitable workforce. 


\section{Reference:}

http://en.wikipedia.org/wiki/work-life_balance

http://www.cipd.co.u]k/subjects/wrkgtime/flexwking/

http:///www.growtalent.com/gptw/Innovative.htm

http://www.wipro.in/resources/whitepapers/ess_channelempcollacf.pdf. p.11-12

The Best companies to work for in India, Business Today: Special Issue, November 20, 2005 . 